\title{
PENERAPAN MODEL DISCOVERY LEARNING UNTUK MENINGKATKAN HASIL BELAJAR MATEMATIKA SISWA KELAS VII SMP LABSCHOOL FIP UMJ
}

\author{
Ismah ${ }^{1 *}$ dan Venni Herli Sundi ${ }^{2}$ \\ ${ }^{1)}$ Pendidikan Matematika, Fakultas Ilmu Pendidikan, Universitas Muhammadiyah Jakarta \\ Jl. KH. Ahmad Dahlan, Cirendeu, Ciputat, Tangerang Selatan \\ ${ }^{2)}$ SMP Labschool Universitas Muhammadiyah JakartaJl. KH. Ahmad Dahlan, Cirendeu, \\ Ciputat, Tangerang Selatan \\ *ismah.fr@gmail.com
}

\begin{abstract}
Abstrak
Tujuan penelitian ini untuk meningkatkan hasil belajar matematika materi himpunan melalui penerapan model pembelajaran discovery learning. Jenis penelitian adalah penelitian tindakan kelas (PTK), dengan subjek dalam penelitian ini adalah siswa kelas VII SMP Labschool Fakultas Ilmu Pendidikan Universitas Muhammadiyah Jakarta tahun ajaran 2018/2019 yang berjumlah 16 orang siswa. Data dari penelitian dikumpulkan melalui pengamatan dan test dari masing-masing siklus. Penelitian ini berlangsung selama dua siklus dan sebelumnya dilakukan tahap pra siklus. Tindakan dikatakan berhasil apabila hasil belajar yang memenuhi kriteria ketuntasan minimal yaitu 75 melebihi 85\% (14 siswa). Analisis data hasil belajar matematika materi himpunan menunjukan adanya peningkatan dari masing-masing tahapan siklus, dimana pada pra siklus dengan pendekatan kontekstual, diketahui data siswa dengan hasil belajar rendah dan tidak memenuhi kriteria ketuntasan minimal sebanyak 3 orang, siswa dengan hasil belajar sedang dan berada pada kriteria ketuntasan minimal sebanyak 2 orang, dan siswa dengan hasil belajar tinggi dan melebihi pada kriteria ketuntasan minimal sebanyak 12 orang. Kemudian pada siklus I, keseluruhan siswa mendapatkan hasil belajar tinggi dan melebihi kriteria ketuntasan minimal. Sedangkan pada siklus II, siswa dengan hasil belajar sedang dan berada pada kriteria ketuntasan minimal sebanyak 2 orang, dan siswa dengan hasil belajar tinggi dan melebihi kriteria ketuntasan minimal sebanyak 14 orang. Hasil penelitian ini menunjukkan bahwa penerapan model pembelajaran discovery learning dapat meningkatkan hasil belajar matematika materi himpunan siswa kelas VII SMP Labschool Fakultas Ilmu Pendidikan Universitas Muhammadiyah Jakarta.
\end{abstract}

Kata Kunci: discovery learning, hasil belajar, matematika, materi himpunan. 


\section{PENDAHULUAN}

Matematika merupakan salah satu bidang ilmu yang dipelajari oleh siswa di tingkat pendidikan nasional dan internasional. Sifat matematika yang abstrak dan merupakan ilmu hitung (angka) menjadikan tidak banyak siswa yang menyukai matematika. Menurut Abdurrahman dalam Agustin (2014), menyatakan bahwa ide manusia tentang matematika berbeda, tergantung pada pengalaman dan pengetahuan masingmasing. Tidak hanya terbatas pada perhitungan tambah dan kurang, kali dan bagi, tetapi ada hal kompleks lain yang memerlukan logika dalam penyelesaiannya. Seperti kemampuan membedakan suatu ukuran, kemampuan mengidentifikasi urutan-urutan, kemampuan menggunakan simbol-simbol abstrak, kemampuan aritmatika, kemampuan spatial, serta short term and long term memory (Fanu dalam Agustin, 2014).

Banyaknya kemampuan dan kompetensi yang ada dalam mata pelajaran matematika ini menyebabkan siswa merasa kesulitan dalam menguasai permasalahan matematis. Selain itu, penggunaan metode pembelajaran konvensional, seperti terbatas pada pendekatan kontekstual yang dilakukan oleh guru membuat siswa hanya sebatas mengetahui sesuatu bukan mampu untuk melakukan sesuatu, sehingga proses belajar tidak berjalan secara efektif. Metode pembelajaran yang konvensional pun turut menambah deret faktor penyebab sulitnya anak memahami materi dalam pembelajaran matematika.

Hasil belajar memiliki peranan yang sangat penting dalam proses pembelajaran, salah satunya pada pembelajaran matematika. Hasil belajar matematika yang tinggi, atau adanya perubahan hasil belajar

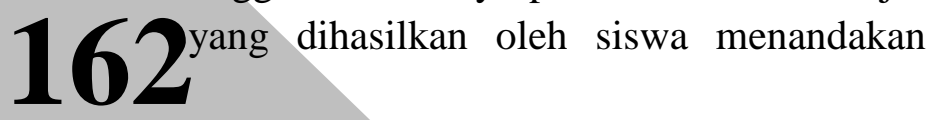

bahwa proses pembelajaran matematika tersebut efektif. Akan tetapi, realita yang dihadapi oleh guru adalah tidak mudah untuk merubah hasil belajar siswa. Diperlukan berbagai strategi pembelajaran yang perlu diterapkan guna meningkatkan hasil belajar siswa.

Kejenuhan adalah salah satu rasa yang sering muncul pada siswa. Siswa merasa jenuh ketika proses pembelajaran di sekolah, terlebih pada pembelajaran matematika yang berkutat pada rumus dan angka-angka. Begitu banyak faktor yang mempengaruhi siswa menjadi jenuh saat belajar, baik dari faktor internal diri siswa maupun faktor eksternal yang berasal dari luar seperti lingkungan belajar, metode serta model pembelajaran yang digunakan, sarana dan fasilitas belajar, dan sebagainya.

Kejenuhan yang dialami siswa tidak hanya mampu menjadikan siswa tersebut malas belajar, juga akan mempegaruhi hasil belajar siswa itu sendiri. Namun, kejenuhan yang dialami siswa pun tidak datang secara tiba-tiba dan begitu saja, ada latar belakang yang mempengaruhinya. Oleh karena itu, guru harus mampu melihat dan memahami latar belakang dari kejenuhan siswa tersebut. Karena, dengan terselesaikannya masalah kejenuhan ini, diharapkan siswa dapat belajar dengan baik dan mencapai prestasi belajar yang memuaskan (Agustin, 2014).

Salah satu materi pelajaran yang membuat siswa jenuh dan kurang memahami adalah materi himpunan. Dimana materi himpunan tersebut disajikan dalam bentuk notasi yang kadang masih sering membingungkan siswa untuk membacanya. Penyampaian materi himpunan yang hanya terbatas pada tulisan di papan tulis pun menjadi faktor penambah materi tersebut kurang dipahami oleh siswa. 
Seperti observasi yang telah dlakukan pada siswa kelas VII SMP Labschool Fakultas Ilmu Pendidikan Universitas Muhammadiyah Jakarta sebelumnya pun menyimpulkan bahwa tidak semua siswa kelas VII mampu memahami materi himpunan ketika guru menjelaskan dengan menulis di papan tulis.

Salah satu alternatif penyelesaian masalah tersebut adalah dengan penggunaan model pembelajaran discovery learning, dimana berdasarkan hasil penelitian yang telah dilakukan oleh Tika Febriana, dkk (2014), model tersebut dapat memperbaiki proses pembelajaran dan meningkatkan hasil belajar matematika siswa pada materi pokok integral. Selain itu, berdasarkan Permendikbud No. 104 (2014), penerapan discovery learning secara berulang-ulang dapat meningkatkan kemampuan penemuan diri individu yang bersangkutan, sehingga pengetahuan itu akan lebih lama diingat dan memungkinkan peningkatan hasil belajar siswa.

Penelitian serupa yang dilakukan oleh Rivai (2017) menyimpulkan bahwa adanya pengaruh model pembelajaran discovery learning terhadap hasil belajar siswa dengan $F_{A}=6,319$. Sedangkan ratarata marginal model pembelajaran discovery learning yaitu 88,6 dan rata-rata marginal model pembelajaran konvensional yaitu 83,8. Hal ini berarti hasil belajar matematika dengan menggunakan model pembelajaran discovery learning lebih baik daripada dengan menggunakan model pembelajaran konvensional.

Model discovery learning adalah model pembelajaran yang menempatkan guru sebagai fasilitator, dimana siswa menemukan sendiri pengetahuan yang belum mereka ketahui dengan dibimbing oleh pertanyaan-pertanyaan guru, LKS, maupun LKK (Mawaddah dan Maryanti,
2016). Pengetahuan yang baru didapatkan oleh siswa akan dilibatkan secara langsung dalam proses pemahaman materi yang diajarkan. Menurut Syah dalam Mawaddah dan Maryanti (2016), tahapan dan prosedur dalam pelaksanaan pembelajaran dengan model discovery learning dikelas secara umum adalah sebagai berikut:

(1) Simulation (simulasi/pemberian ransangan), yakni memulai kegiatan proses belajar mengajar dengan mengajukan pertanyaan, anjuran membaca buku, dan aktivitas belajar lainnya yang mengarah pada persiapan pemecahan masalah;

(2) Problem

statement (penyataan/identifikasi masalah), yakni memberi kesempatan kepada siswa untuk mengidentifikasi sebanyak mungkin agenda-agenda masalah yang relevan dengan bahan pelajaran, kemudian salah satunya dipilih dan dirumuskan dalam bentuk hipotesis (jawaban sementara atas pertanyaan masalah);

(3) Data collection (pengumpulan data), yakni memberikan kesempatan pada siswa untuk mengumpulkan informasi sebanyak-banyaknya yang relevan untuk membuktikan benar atau tidaknya hipotesis;

(4) Data processing (pengolahan data), yakni mengolah data dan informasi yang telah diperoleh oleh para siswa melalui wawancara, observasi, dan sebagainya, lalu ditafsirkan;

(5) Verification (verifikasi/pentakhiran), yakni melakukan pemeriksaan secara cermat untuk membuktikan benar atau tidaknya hipotesis yang ditetapkan, dihubungkan dengan hasil data processing;

(6) Generalization (generalisasi), yakni menarik sebuah simpulan yang dapat- 
dijadikan prinsip umum dan berlaku untuk semua kejadian atau masalah yang sama, dengan memperhatikan hasil verifikasi.

Berdasarkan uraian diatas, dapat dirumuskan masalah pada penelitian ini adalah "Apakah penerapan model pembelajaran discovery learning dapat meningkatkan hasil belajar matematika materi himpunan di SMP Labschool Fakultas Ilmu Pendidikan Universitas Muhammadiyah Jakarta?". Oleh karena itu, dapat diketahui bahwa tujuan dari penelitian ini adalah untuk mengetahui apakah penerapan model pembelajaran discovery learning dapat meningkatkan hasil belajar matematika materi himpunan di SMP Labschool Fakultas Ilmu Pendidikan Universitas Muhammadiyah Jakarta.

\section{METODE PENELITIAN}

Penelitian yang dilakukan merupakan jenis penelitian tindakan kelas (PTK). Dalam pelaksanaan PTK, peneliti bertindak sebagai pengamat dari keberhasilan penerapan model pembelajaran discovery learning terhadap hasil belajar matematika pada masing-masing siklusnya. Subjek penelitian adalah siswa kelas VII SMP Labschool Fakultas Ilmu Pendidikan Universitas Muhammadiyah Jakarta tahun ajaran 2018/2019 yang berjumlah 16 orang siswa. Data dari penelitian ini dikumpulkan melalui pengamatan dan test dari masingmasing siklusnya. Penelitian ini berlangsung selama dua siklus, yaitu siklus I dan siklus II, dan sebelumnya dilakukan tahap pra siklus. Adapun, rangkaian siklus dalam penelitian ini adalah sebagai berikut:

\section{Pra Siklus}

Tahap ini dilakukan pada pertemuan pertama kegiatan penelitian, dimana siswa diberikan soal pre test untuk melihat hasil belajar matematika materi himpunan dengan pendekatan kontekstual.

\section{Siklus I}

Setelah mendapatkan data hasil pre test mengenai hasil belajar matematika siswa pada materi himpunan dengan pendekatan kontekstual, penelitian masuk pada tahap siklus I yang dilakukan pada dua pertemuan, yaitu pertemuan kedua dan ketiga kegiatan penelitian. Treatment yang diberikan pada tahap ini adalah: pada pertemuan kedua dilakukan kegiatan belajar mengajar dengan model pembelajaran discovery learning berdasarkan tahapan dan prosedur pelaksanaannya. Kemudian pada pertemuan ketiga dilakukan review materi yang telah diajarkan pada pertemuan kedua, serta pemberian test siklus I.

\section{Siklus II}

Setelah mendapatkan data hasil test siklus I, penelitian dilanjutkan dengan masuk pada tahap siklus II. Tahap siklus II dilakukan pada pertemuan keempat dan kelima. Tahap siklus II ini tidak jauh berbeda dengan tahap siklus I. Perbedaan dari treatment yang diberikan hanya sebatas pada masalah yang diberikan pada siswa sedikit diubah pada pertemuan keempat. Setelah itu, siswa tetap mereview materi yang telah diberikan pada pertemuan keempat, dan diberikan test siklus II pada pertemuan kelima.

Setelah didapat data hasil tahap pra siklus, siklus I, dan siklus II, peneliti akan melihat dan menganalisis adanya peningkatan hasil belajar matematika siswa pada setiap siklusnya. Kemudian, tindakan pembelajaran dianggap berhasil jika nilai 
dari $85 \%$ siswa pada tahap siklus II mencapai standar ketuntasan minimal, dimana standar ketuntasan minimal tersebut adalah 75. Jika hasil test pada tahap siklus II tidak mencapai standar ketuntasan minimal tersebut, maka tindak pembelajaran dianggap gagal diulang kembali pada siklus berikutnya hingga mencapai indikator keberhasilan yang telah ditetapkan sebelumnya (Setyani, dkk, 2015).

\section{HASIL DAN PEMBAHASAN}

\section{A. Pra Siklus}

Pada tahap pra siklus, peneliti melakukan penilaian awal untuk mengetahui hasil belajar matematika siswa kelas VII yang diajarkan dengan pendekatan kontekstual. Tahap pra siklus ini dilaksanakan pada hari Senin dan Selasa, tanggal 23-24 Juli 2018. Pada pertemuan pertama ini, peneliti hanya mengambil waktu selama satu jam pelajaran, dari tiga jam pelajaran matematika yang sedang berlangsung. Pre test tersebut berisi soal-soal mengenai himpunan yang telah dipelajari sebelumnya. Kemudian, dari hasil pre test dapat diketahui sebagai berikut:

Tabel 1. Data Hasil Belajar Matematika Pra Siklus

\begin{tabular}{lc}
\hline Hasil Belajar Matematika Siswa & Nilai \\
\hline Rendah (0-60) & 3 \\
\hline Sedang (61-75) & 1 \\
\hline Tinggi (76-100) & 12 \\
\hline
\end{tabular}

Berdasarkan data pada tabel 1, dapat diketahui bahwa ada tiga orang siswa yang mendapatkan hasil belajar rendah, kemudian ada satu orang siswa yang mendapatkan hasil belajar sedang, dan ada 12 orang yang mendapatkan hasil belajar tinggi pada materi himpunan. Tiga orang siswa yang mendapatkan hasil belajar rendah tersebut tidak memenuhi standar ketuntasan minimal, dengan nilai masingmasing ketiga siswa tersebut adalah 10, 40, dan 55. Adapun, satu orang yang mendapatkan hasil belajar sedang tersebut memenuhi standar ketuntasan minimal, dengan nilai yang didapatkan adalah 75 . Sehingga dapat disajikan dalam bentuk diagram seperti berikut ini:

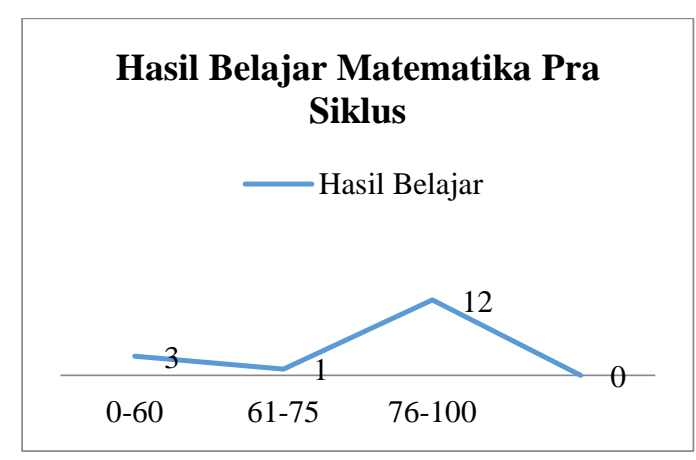

Gambar 1. Diagram Hasil Belajar Matematika Pra Siklus

\section{B. Siklus I}

Tahap siklus I dilaksanakan pada empat kali pertemuan kelas, yaitu pertemuan ketiga hingga keenam. Tahap ini diawali pada hari pertemuan ketiga, yaitu hari Senin, tanggal 30 Juli 2018 dengan memberikan pengenalan dan pembelajaran mengenai himpunan dengan pendekatan discovery learning. Tahap ini berlangsung selama dua jam pelajaran matematika. Selama penelitian ini berlangsung, dapat diamati bahwa masih adanya siswa yang tidak memperhatikan materi dan instruksi guru. Meskipun demikian, masih ada siswa yang kooperatif mendengarkan dan menjalankan instruksi guru. Sehingga diperlukan strategi agar siswa mudah memahami materi dan instruksi guru.

Pada pertemuan keempat dan kelima, yaitu hari Selasa, tanggal 31 Juli 2018 dan hari Senin, tanggal 6 Agustus 2018. Selama tiga jam pelajaran, guru melakukan langkah pembelajaran sesuai dengan tahapan dalam 
discovery learning. Tahap 1, simulation, guru memperlihatkan gambar terkait dengan kumpulan benda-benda seperti lapak pak budi, makanan dan minuman yang terbuat dari kedelai, binatang ternak dan lainnya. Tahap 2, problem statement, siswa diberikan kesempatan untuk mengidentifikasi dengan menyebutkan jenis kumpulan dari objek-objek tertentu. Tahap 3, data collection, siswa membuat kumpulan-kumpulan sebanyak-banyaknya dengan objek-objek tertentu berdasarkan tulisan yang berisi cerita tentang 3 orang peternak yang ditayangkan oleh guru dalam slide presentasi. Tahap 4, data processing, setelah siswa membuat kumpulan dari objek-objek tertentu kemudian kumpulan tersebut di klasifikasi sesuai dengan jenis himpunan dan bukan himpunan. Tahap 5, verification, guru bersama siswa melakukan koreksi terkait dengan pekerjaan siswa yang sudah dilakukan. Tahap 6, generalization, guru menyimpulkan secara keseluruhan berdasarkan pada hasil pekerjaan siswa. Pada pertemuan berikutnya hari Selasa, tanggal 7 Agustus 2018, guru memberikan test kepada siswa dengan bentuk soal yang diberikan masih berpola dan menggunakan indikator yang sama dengan pertemuan kedua pada saat prasiklus, namun dibedakan angka dan operasinya.. Dari test tersebut dapat diketahui hasil belajar matematika siswa pada siklus I adalah sebagai berikut:

Tabel 2. Data Hasil Belajar Matematika Siklus I

\section{Hasil Belajar Matematika Siswa Nilai}

\begin{tabular}{lc}
\hline Rendah (0-60) & 0 \\
\hline Sedang (61-75) & 0 \\
\hline Tinggi (76-100) & 16 \\
\hline
\end{tabular}

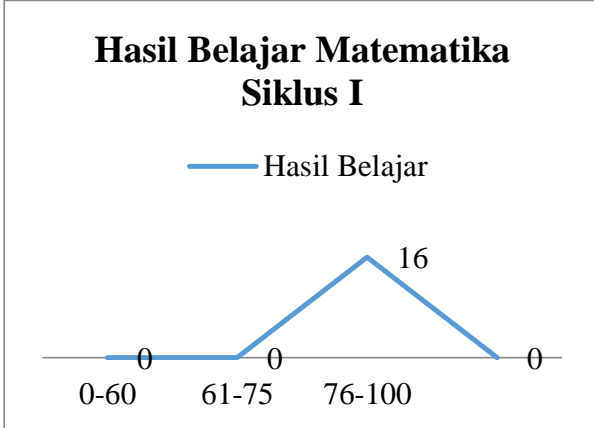

Gambar 2. Diagram Hasil Belajar Matematika Siklus I

Berdasarkan pada Tabel 2 dan Gambar 2, dapat diketahui bahwa keseluruhan hasil belajar matematika siswa meraih kategori tinggi. Sehingga terdapat peningkatan hasil belajar antara pembelajaram dengan pendekatan kontekstual dan pendekatan discovery learning.

Pada siklus treatment sudah dapat dikatakan berhasil, namun treatment tetap diberikan pada pertemuan berikutnya dikarenakan materi yang disampaikan pada siklus 1 masih tergolong mudah, yaitu pengenalan himpunan hingga penulisan notasi himpunan.

Berdasarkan hasil refleksi yang dilakukan, diputuskan untuk melakukan siklus II, dengan treatment yang sama tetapi materi yang dibahas tentang operasi himpunan yang tergolong lebih sulit. Hal ini dilakukan untuk melihat kekonsistenan kenaikan hasil belajar yang diperoleh di siklus II melalui pendekatan discovery learning.

\section{Siklus II}

Tahap siklus II juga dilaksanakan pada tiga kali pertemuan kelas. Tahap ini diawali pada hari pertemuan ketujuh, yaitu hari Senin, tanggal 13 Agustus 2018, dan pertemuan kedepan hingga kesembilan hari Senin dan Selasa, tanggal 20-21 Agustus 
2018. Tahap ini berlangsung selama dua jam pelajaran matematika. Selama penelitian ini berlangsung, dapat diamati bahwa siswa sudah mulai kondusif, namun ada dua orang siswa memperlihatkan perilaku yang berbeda dari biasanya.

Dua orang siswa tersebut dengan inisial Fr dan St adalah siswa berprestasi, tetapi ketika treatment diberikan di siklus II, kedua siswa tersebut dalam pengamatan guru terlihat tidak menanggapi instruksi yang diberikan oleh guru, kedua siswa tersebut lebih banyak bercanda pada saat kegiatan belajar berlangsung.

Tahapan yang dilakukan guru mengikuti langkah dalam discovery learning seperti yang dilakukan pada siklus I yaitu mulai dari simulation hingga generalization.

Pada pertemuan kesepuluh, yaitu hari Senin, tanggal 28 Agustus 2018. Selama tiga jam pelajaran, guru membahas kembali permasalahan yang telah dikerjakan pada pertemuan sebelumnya. Setelah itu, guru memberikan test kepada siswa dengan bentuk soal yang diberikan terkait materi operasi himpunan, serta variasi soal lebih banyak daripada soal yang diberikan pada test siklus I. Dari test tersebut dapat diketahui hasil belajar matematika siswa pada siklus II seperti yang nampak pada Tabel 3 dan Gambar 3 berikut ini:

Tabel 3. Data Hasil Belajar Matematika Siklus II

\begin{tabular}{lc}
\hline Hasil Belajar Matematika Siswa & Nilai \\
\hline Rendah (0-60) & 0 \\
\hline Sedang (61-75) & 2 \\
\hline Tinggi (76-100) & 14 \\
\hline
\end{tabular}

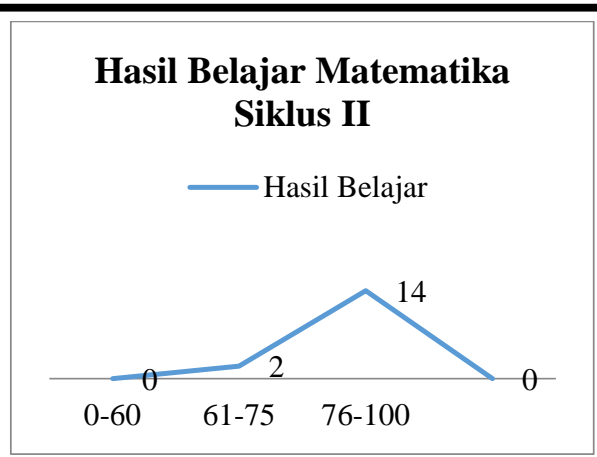

Gambar 3. Diagram Hasil Belajar Matematika Siklus II

Berdasarkan pada Tabel 3 dan Gambar 3, dapat diketahui bahwa hasil belajar matematika siswa meraih dua kategori, yaitu 2 orang siswa dengan hasil belajar sedang dan 14 orang siswa dengan hasil belajar tinggi. Terdapat penurunan dari siklus I, dimana pada siklus I total siswa yang mendapat hasil belajar tinggi sebanyak $100 \%$. Akan tetapi, kedua siswa yang mendapatkan hasil belajar matematika sedang tetap dikatakan menenuhi indikator keberhasilan belajar, karena nilai yang didapatkan oleh keduanya memenuhi standar ketuntasan minimal yaitu 75 . Selain itu, dapat diketahui pula bahwa terdapat peningkatan hasil belajar antara pembelajaran dengan pendekatan kontekstual dan pendekatan discovery learning.

Kedua siswa dengan hasil belajar berkategori sedang, salah satunya adalah siswa Fr dimana dari hasil pengamatan yang telah dilakukan terlihat perilaku siswa cenderung berubah menjadi kurang fokus ketika kegiatan belajar berlangsung dan kurang memperhatikan instruksi guru. Satu orang siswa lagi adalah siswa berinisial $\mathrm{Rh}$. Berdasarkan hasil pada pra siklus diketahui siswa $\mathrm{Rh}$ memperoleh nilai terkecil, namun mengalami peningkatan pada siklus I, tetapi pada siklus II hasil belajar yang diperoleh mengalami penurunan. Hasil perbincangan guru kepada siswa $\mathrm{Rh}$ setelah tes dilakukan dan diperoleh hasil, Rh mengatakan bahwa materinya lebih sulit ketimbang materi yang 
dibahas pada siklus 1. Oleh karena itu keberhasilan suatu pendekatan pembelajaran dapat dipengaruhi berdasarkan tingkat kesukaran dari materi dan soal yang diberikan.

Berdasarkan data hasil belajar matematika siswa dari masing-masing siklus, yaitu pra siklus, siklus I, dan siklus II, dapat disimpulkan bahwa terdapat peningkatan hasil belajar matematika siswa pada materi himpunan meskipun pada siklus II terjadi penurunan hasil belajar siswa dari tinggi menjadi sedang sebanyak 2 orang siswa. Akan tetapi, penurunan tersebut tidak berdampak signifikan, karena jika dilihat dari tahap pra siklus menuju siklus I, 2 orang siswa tersebut mengalami peningkatan hasil belajar matematika. Kemungkinan terjadinya penurunan tersebut dikarenakan selama masa siklus II, kedua siswa ini lebih sulit memahami karena tidak mendengarkan instruksi guru, dan perbedaan soal yang menjadi lebih banyak variasinya dibandingkan pada siklus I. Sehingga, data peningkatan hasil belajar matematika siswa dari masing-masing siklus dapat disajikan sebaga berikut:

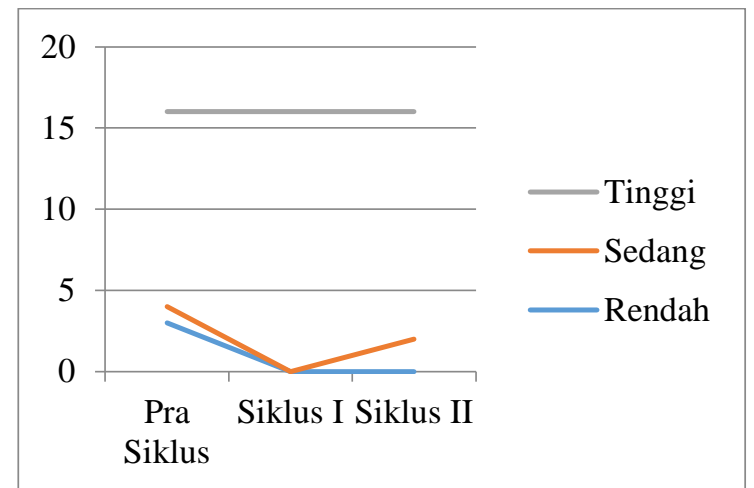

Gambar 4. Diagram Hasil Belajar

Matematika Masing-Masing Siklus
Oleh karena itu, dapat disimpulkan bahwa ketiga siklus tersebut memenuhi indikator keberhasilan pembelajaran, dimana siswa yang mendapatkan hasil belajar matematika materi himpunan dengan pendekatan discovery learning berada diatas $85 \%$, sehingga terdapat peningkatan hasil belajar matematika materi himpunan pada siswa kelas VII SMP Labscshool Fakultas Ilmu Pendidikan Universitas Muhammadiyah Jakarta melalui penerapan model pembelajaran discovery learning pada tahun ajaran 2018/2019.

\section{SIMPULAN}

Berdasarkan hasil penelitian yang telah dilakukan, dapat disimpulkan bahwa penerapan model pembelajaran discovery learning dapat meningkatkan hasil belajar matematika materi himpunan siswa kelas VII SMP Labschool Fakultas Ilmu Pendidikan Universitas Muhammadiyah Jakarta. Peningkatan tersebut dapat dilihat dari masing-masing data dan diagram hasil belajar matematika siswa dari ketiga siklus.

\section{UCAPAN TERIMA KASIH}

Ucapan terimakasih ditujukan kepada Direktorat Jenderal BELMAWA RISTEKDIKTI atas Hibah Program Penugasan Dosen ke Sekolah tahun 2018 yang diamanahkan kepada Fakultas 


\section{DAFTAR PUSTAKA}

Agustin, Mubiar. 2014. Permasalahan Belajar dan Inovasi Pembelajaran: Panduan untuk Guru, Konselor, Psikolog, Orang Tua, dan Tenaga Kependidikan. Bandung: Refika Aditama.

Febrina, Tika, dkk. 2014. Penerapan Model Dicovery Learning untuk Meningkatkan Hasil Belajar Matematika Siswa Kelas XI MIA 1 SMA Negeri 8 Pekanbaru. Artikel Dipublikasi. Riau: Universitas Riau.

Mawaddah, S. dan Maryanti, R. 2016. "Kemampuan Pemahaman Konsep Matematis Siswa SMP dalam Pembelajaran Menggunakan Model Penemuan Terbimbing (Discovery Learning)". EDU-MAT: Jurnal Pendidikan Matematika, Vol 4 (1), pp: 76-85.

Permendikbud Nomor 104 Tahun 2014 tentang Pembelajaran pada Pendidikan Dasar dan Pendidikan Menengah. Jakarta: Kemendikbud.

Rivai, M. Anwar. 2017. Penerapan Pembelajaran Matematika dengan Model Discovery Learning terhadap Hasil Belajar Matematika Ditinjau dari Kreativitas Siswa Kelas VII SMP Negeri 2 Baki Sukoharjo. Skripsi Dipublikasi. Solo: Universitas Muhammadiyah Surakarta.

Setyani, Mutia Rahma, dkk. 2017. "Penerapan Lego Bricks dalam Pembelajaran Sebagai Strategi untuk Meningkatkan Kecerdasan Matematis Siswa dalam Menghitung Bilangan Berpangkat”. FIBONACCI: Jurnal Pendidikan Matematika dan Matematika, Vol 3 (1), pp: 53-64. 